complexity of these problems demands the services of a team of workers, extending over many years, and can only be carried out with the aid of a central organisation, which should serve as a centre both for receiving questions and transmitting information. It is suggested that there should be established forthwith in India a central institute of animal population and migration, staffed by competent zoologists whose main function would be the study of vertebrate populations and migrations from all points of view.

\section{Length of the Small Intestine}

Prow. J. B. Creland, of the University of Adelaide, writes: "In Nature of March 17, 1945 (p. 327), the maximum length of the small intestine quoted is $28 \mathrm{ft} .4 \mathrm{in}$. In the Medical Journal of Australia of September 30,1944 (p. 359), I have given the lengths of the small intestine (not including the duodenum) in a hundred post-mortems at Adelaide. The longest five, all being males, were $30 \mathrm{ft}$., $31 \mathrm{ft}$., $33 \mathrm{ft}$., $35 \mathrm{ft}$., and $37 \mathrm{ft}$. ; the longest in a female subject was $29 \mathrm{ft} . "$

\section{Science and the Welfare of Mankind}

A Conference on "Science and the Welfare of Mankind" will be held in the Beaver Hall, Garlick Hill, London, E.C.4, during February 15-17. The Conference is being organised by the Association of Scientific Workers in co-operation with the Association of University Teachers, the Institute of Professional Civil Servants and the British Association of Chemists. There will be an introductory session dealing with "Science and World Needs" (chairman, Sir Robert Robinson). The three following sessions will deal with : "The Implications of Recent Scientific Development" (chairman, Sir Richard Gregory) ; "The Responsibilities of Scientists to Modern Society" (chairman, Prof. A. V. Hill) ; "The Organisation of Science" (chairman, Sir Robert Watson-Watt). Among the speakers at the Conference will be $\mathrm{Mr}$. Herbert Morrison, Prof. P. M. S. Blackett, Prof. M. L. Oliphant, Dr. H. L. Richardson, Prof. B. Farrington, Prof. J. D. Bernal, Mr. A. Horner, Dr. Julian Huxley and representative foreign men of science. The Conference will be summed up by Sir Robert Watson-Watt. Tickets for admission (2s. $6 d$. per session, 7s. 6d. for the whole Conference) and further information can be obtained from the Association of Scientific Workers, 15 Half Moon Street, London, W.1.

\section{Summer School on Theoretical Physics in Industry}

A summer school will be held in the H. H. Wills Physical Laboratory in co-operation with the Institute of Physics, during May 30-June 6. The subjects to be studied will cover the general field of conduction of electricity in non-metals and will include luminescence, dielectric phenomena and reactions in solids. The course is intended mainly for members of the research staffs of Government and industrial laboratories who are engaged on experimental research in these subjects. Further particulars may be obtained from the Director of the Department of Adult Education, University, Bristol, 8.

\section{German Aeronautical Developments}

WHEN an exhibition of German aircraft was held last autumn at the Royal Aircraft Establishment, Farmborough, the Minister of Aircraft Production, Mr. John Wilmot, was convinced that the display should also be made available to the general public as soon as possible, at a central site. As a result, an exhibition of German aeronautical developments will be held under the auspices of the Ministry of Education at the Science Museum, South Kensington, commeneing February 14. The exhibition will be open on weekdays from 10 a.m. to 6 p.m., and Sundays from 2.30 p.m. to 6 p.m. for three months. The exhibits are selected from those shown at Farnborough. They comprise a number of typical German military aircraft, including a jet-propelled fighter, flying bomb, the gyro-kite for use with U-boats, a piloted V1, a V2-rocket and radio-controlled rocket weapons. The exhibition coincides with the post-war reopening of the Science Museum for, in addition, the museum also has a series of exhibitions relating to atomic energy, X-rays and the quartz crystal clock.

\section{Announcements}

Dr. J. S. Mrrchell, of St. John's College, Cambridge, has been appointed to the newly established chair of radiotherapeutics in the University of Cambridge.

According to The Times correspondent, the University of Berlin was formally reopened on January 29. All arrangements for the reopening, the appointment of staff, and examining the political antecedents of students were made under Russian supervision. There are about three thousand students in all, and there is a teaching staff of a hundred professors and about a hundred and fifty lecturers.

Elections to three Beit Fellowships for Scientific Research will take place on or about July 6. Candidates must be of European descent by both parents and hold a degree or equivalent qualifications of a university of the British Empire. The age limit is twenty-five. Forms of application (returnable before April 6) and all information may be obtained, by letter only, addressed to the Registrar, Imperial College, South Kensington, London, S.W.7.

The Staveley Coal and Iron Co., Ltd., is establishing a Central Research Department, which will include the research activities of its subsidiary com. pany, Bradley and Foster, Ltd., of Darlaston, in order to co-ordinate all its chemical and metallurgical research. The new Department will be located at Staveley Works, near Chesterfield, and will be known as the Staveley/Bradley Foster Research Department. Its principal object will be the intensification of research and development in all aspects of the manufacture of chemicals and iron and their utilization. Dr. J. H. Hurst, technical director of Bradley and Foster, Ltd., has been appointed director of research to the Staveley Co., and the new Department will be under his direction.

WE have received a pamphlet entitled "50 Years of Scientific Instrument Manufacture" from the Cambridge Instrument Co., Ltd., this being a reprint of an article in Engineering during May and June 1945. The book of twenty-six pages is fully illustrated and gives an interesting story of the development of this well-known firm since its foundation in 1895 by A. G. Dew-Smith and Horace Darwin, the various instruments for which it has become famous being described. There can be no doubt that the company has materially assisted research and the scientific control of industry by its products. Copies of the pamphlet can be obtained from the Publicity Department, Cambridge Instrument Co., Ltd., 13 Grosvenor Place, London, S.W.1. 